\title{
Improvement of Institution of Parole Release and Its Implementation Practices
}

\author{
Igor Olegovich Antonov ${ }^{1}$ \\ Andrey Yurievich Verin ${ }^{1}$ \\ Marina Evgenievna Klyukova ${ }^{1}$ \\ Elena Vladimirovna Nechaeva ${ }^{2 *}$ \\ ${ }^{1}$ Kazan Federal University \\ ${ }^{2}$ Federal State Budgetary Educational Institution of Higher Education, \\ IN Ulianov Chuvash State University \\ ${ }^{*}$ Corresponding Author
}

Doi: 10.36941/jesr-2019-0025

\section{Abstract}

The scientific article is devoted to the study of parole from serving a sentence as the most important incentive institution of criminal and penal law. The study of this type of exemption from punishment revealed a number of moments not sufficiently regulated by the legislator, affecting the grounds for both the application and non-application of parole. As a basis for exemption from criminal punishment, not any assessment of the degree of correction of the convicted person was recorded, but only one that contributes to acceptable correction and positive resocialization of the offender without actually serving the unserved part of the criminal sentence. It is important that the legislator determines the inadmissibility of unjustified release of convicts from serving their sentences. The problematic issues of applying this institution are: the grounds for parole, which are not sufficiently clarified; situations concerning the objectivity of decision-making on granting or refusal to grant parole; the absence of a legislative specific specialized state body endowed with powers to control the behavior of those released on parole, capable of effectively implementing them. The article proposes solutions to these problems, providing a qualitative increase in the effectiveness of the application of the considered incentive institution.

Keywords: grounds for exemption from punishment, parole, criminal punishments, convicted, judicial practice, control of parole

\section{Introduction}

The conditional release institution (hereinafter - UDO) is one of the few encouraging institutions, and represents the state's refusal to punish the behavior of a convicted person who is actually serving a sentence of imprisonment, under the condition of law-abiding behavior during the probationary period. Each convict, regardless of the category of the crime he committed, actively seeks to receive the possibility of parole.

According to judicial statistics provided by the Judicial Department of Russia, since 2012, there has been a simultaneous decrease in both the total number of appeals (petitions) examined by the courts and the number of those approved. The district courts of the Russian Federation examined materials of applications for parole in 2012 in respect of 174854 people, of which 8989 
or $51.4 \%$ were satisfied (Review of judicial practice of parole from serving a sentence). In 2018, 99 646 applications for parole from prison were examined, of which 49292 persons were granted (Statistical data of the judicial department under the Supreme Court of the Russian Federation). The above statistics indicate not only the not very active application of Art. 79 of the Criminal Code of the Russian Federation (hereinafter - the Criminal Code) in practice, but also on changing the "quality" composition of convicts.

According to studies of this type of exemption from punishment (Kachalova, 2015), there are currently a number of controversial issues not regulated by the legislator regarding the grounds for both the use and non-use of parole.

In Russia, when the courts apply UDD from serving, as law enforcement practice shows, sometimes unreasonable decisions are made to release convicts from serving their sentences. To date, there is no clear explanation of the grounds for parole for the law enforcer and the state body has not been defined by law, whose competence includes control over the behavior of those released on parole. Other problems are known that need an urgent solution. The amendments to the legislation on parole determine the need to continue scientific research in this area.

\section{Methods}

The methodological basis of our study was, first of all, the fundamental dialectic method of cognition of social and legal phenomena in the field under consideration, analysis methods, as well as system-structural and logical-legal methods. Also, when conducting the study, the statistical method was widely used, which made it possible to identify the dynamics and prevalence of the use of the UDO institute.

One of the means of studying legal phenomena is considered to be the comparative legal method, since the need to analyze foreign experience in the regulation and application of the institution in question remains relevant for its use in Russia, which predetermined our interest in a wide range of foreign studies in this area. Among them are the works of such scientists as: $S$. Aral (Aral et al., 2002), P. Bennett (Crewe et al., 2014), A. Denkers (Aarten et al., 2014), I.A. Efremova (Efremova \& Razgildiev, 2016), A. Freiberg (Freiberg, 2011), A. Moon (Moon, 2013), J. Petersilia (Rhine et al., 2015), J. Simon (Simon, 2010) and others.

\section{Results and Discussion}

The institution of pre-trial detention has been and remains the key, both in criminal and criminallyexecutive law. Confirmation of this assessment is the great attention to it from the side of the legislator (repeated changes to the Criminal Code of the Russian Federation and the Criminal Executive Code of the Russian Federation (hereinafter - the Criminal Code of the Russian Federation), as well as from scientists and practitioners (numerous publications on this issue). Nevertheless, some issues of improving the institution of parole remain on the agenda today.

In the context of the last revision of part 4.1 Art. 79 of the Criminal Code of the Russian Federation, when considering applications for parole from serving a sentence, the courts take into account the convict's attitude to study, labor duties, his behavior in general for the entire term of serving the sentence. In addition, it is the duty of the court to take into account the incentives and penalties imposed on the convicted person, as well as his attitude to the crime committed (repentance, indifference, etc.).

The grounds for parole include the actual (partial or full) compensation for the damage caused or another option for redressing the damage caused by the criminal act, as well as the opinion of the administration of the correctional institution on the appropriateness of the parole of the particular convict.

New wording of part: 1 . of Art. 79 of the Criminal Code, which refers to redress fordamagea caused by a crime, in the amount determined by a court decision, gave rise to certain difficulties for law enforcement agencies.

It is not entirely clear what exactly the amount of damage should be compensated by the convicted person in order for it to be acceptable for a positive decision on the issue of parole, and 
what should be the methodology for its calculation. According to law enforcers, the legislator does not yet give exact answers to these questions.

Practitioners consider the introduction of such a condition unfair, since for many convicts, especially those who have committed crimes in the economic sphere, the issue of release by parole is either difficult or impossible at all.

At the discussion stage of the bill, under the act, the experts "noted the imbalance in this formulation, which effectively binds the Institute of PAROLE for redemption (Drozdov \& Orlov, 2016). If the convicted person was able to pay only a small part, but at the same time was conscientious about his duties, the court may refuse to satisfy the application for parole. In another situation, when the amount of damage to the victim was paid, but other stipulated parameters of the procedure were executed by the convict in bad faith, the court will most likely satisfy the request of the convict.

Often, convicts sincerely wish to compensate for the harm caused by the crime, at least in some part, but objectively they do not have such an opportunity. Currently, employment in penitentiary institutions is not possible for all convicted persons. Those convicts who are employed receive wages, the size of which does not allow in most cases to solve the problem of compensation for harm.

Of course, the decision of the Plenum of the Supreme Court of the Russian Federation of April 21, 2009 contains an indication that in cases where the damage caused by a crime is not compensated in a civil suit for objective reasons (disability, the presence of diseases that impede employment, and the inability to find a job for a limited number of jobs, etc.), the court does not have the right to refuse parole from serving a sentence solely on this basis (Resolution of the Plenum of the Supreme Court of the Russian Federation of April 21, 2009). However, this again puts the convicted in a different legal framework.

We share the policy chosen by the legislator to compulsorily take into account when solving issues of parole, the positive dynamics of the repayment of civil claims by convicts, however, we believe that the term "partial compensation for harm caused by a crime" should contain specific criteria for its calculation. Uncertainty in the position of Part 1 of Art. 79 of the Criminal Code of the Russian Federation can be eliminated by setting limits of this size - to consider partial compensation for damage to an amount of at least half of the size of the damage caused. It is necessary to consolidate the proposed interpretation in the explanations of the Plenum of the Supreme Court of the Russian Federation.

There is a need to improve the procedure for submitting of convicts to parole who have been in jail for a long time in order to apply a preventive measure in the form of detention, and then waited for the court decision to enter into legal force.

A situation may arise when, even before the sentence comes into legal force, the person has actually served the period necessary to provide the opportunity for parole. Changes introduced by the Federal Law of 07/03/2018 in Art. 72 of the Criminal Code of the Russian Federation on the setoff in the period of imprisonment of the time of the person's detention, the convicted person can receive such a factual opportunity earlier than the convicted person serving his sentence in a correctional institution. However, in practice this procedure established by the legislator is impossible to implement for the following reasons: 1) correctional facilities for convicted persons are not implemented in pre-trial detention centers; 2) the administration of the pre-trial detention center does not have the opportunity to give an opinion on the advisability of parole and determine the degree of correction of the convicted person (in fact, there are no grounds for parole). For convicted offenders of minor and medium gravity in this situation, getting parole is not easy.

By improving the procedure for conditionally early release from punishment in the conditions of pre-trial detention centers, we see a change in the criteria for release, in particular, to create the possibility of receiving parole if there is, for example, an opinion from the administration of the pretrial detention center, and consider the condition for full or partial compensation for harm caused by the crime as the basis for a possible cancellation UDO, if after release such a convict does not take the necessary measures in this direction (Drozdov \& Orlov, 2016).

Considering practice of application of UDO, the following list of the duties established for the released persons can be considered acceptable: a) not to change the residence and the place of 
work without the corresponding notification of Supervisory authority; b) it is obligatory to be employed or to register in employment authorities within 1 month after UDO; C) not to leave the dwelling in certain time of day if it is not connected with work in shifts; d) not less than 2 times a month to be on registration in Supervisory authority; d) to participate in financial support of a family; (e) to compensate for the damage caused or otherwise to make amends for the damage caused by the crime; ( $g$ ) not to communicate with persons known to him engaged in criminal activities or convicted of crimes; (h) not to visit cultural and recreational places, especially places of drinking alcohol; and) to assist the employee of the Supervisory authority in carrying out educational and Supervisory activities (Rybakov, 2015).

We believe that the list of duties should be strictly defined and exhaustive.

It is important that each restriction for the convict is based on the rule of law. At the same time, the terms of reference for each convict should be established on the basis of the principle of individualization of the execution of sentences. We consider it possible to fix the above procedure in part 2 of Article 79 of the Criminal Code.

The issue of objectivity of court decisions on granting or refusing to provide parole requires attention. Many have doubts about this issue, both among jurists and ordinary citizens. Corruption in resolving issues related to providing convicts with the opportunity to quickly free themselves from serving their sentences penetrated both the judicial community and the institutions of the penal system. A change in the situation for the better is possible by expanding public control over decisions made so that no one can hide their interests by the apparent legitimacy of decisions (Rybakov, 2015).

It helps to counter corruption schemes by widely publicizing the facts of bribery or other prejudice when deciding on the issue of parole. For example, in correctional institutions of a number of regions, money from 40 to 60 thousand rubles was collected from convicts. depending on specific circumstances, to provide a positive profile to the court (Barygina, 2014).

That is why it is objectively necessary to provide for the mandatory participation in the consideration of applications for parole of representatives of human rights ombudsmen in the entities, as well as members of public monitoring commissions with the provision of the latter with control powers.

Another problem in parole is the control of parolees. Today, there is practically no specialized body performing such functions. The court must establish control over convicts released on parole (fixing the results of the correction).

The established right of the courts to assign to convicts released on parole certain obligations is not really ensured by the authority of the state body to monitor their compliance.

Control is carried out by district inspectors at the place of permanent residence of the released person. The basis for such control is Order of the Ministry of Internal Affairs of Russia dated 12/31/2012 No. 1166 "Issues of organizing the activities of district police officers". This form of control is ineffective - parole does not achieve its goals.

In accordance with the ongoing criminal law reform and reform plans of the penitentiary system, the penitentiary inspectorate should have become the bodies that exercise control over parole. Actually, the penitentiary inspectorates carry out control in relation to probationers, to persons who have been granted a delay in serving their sentences.

The control procedure for persons released under parole is not reflected in the law. Therefore, we consider it appropriate to consider the possibility of including in the PEC of the Russian Federation a chapter regulating the issues of exercising control over parole persons, by analogy with chapter 24 of the PEC of the Russian Federation with regard to probationers. We agree with the proposals to rename section V of the Penal Code of the Russian Federation as follows: "Control over the behavior of conditionally convicted and parole persons" (Ratushny, 2016).

In accordance with the foregoing, we consider it necessary to change the title of Section 8 , "Monitoring of Conditionally Sentenced" to "Monitoring of Conditionally Sentenced and Parole" and supplemented with Chapter 25, "Monitoring the conduct of persons released on parole". In this regard, amendments should also be made to the Regulation on criminal executive inspections in terms of providing them with authority to control the behavior of parole persons.

To implement the above proposals, it is necessary to regulate the procedure for imposing and 
types of penalties applicable to persons on parole, as well as the procedure for their repayment and possible withdrawal.

The reason for the cancellation of parole may not be any administrative misconduct of a person, but only violations of public order, for which the perpetrator reasonably incurred administrative liability prescribed by law.

The proposed ways to improve the application of the institution of parole are not only of theoretical but also of practical importance, since they pursue the goals of exact and strict observance of the law and uniform practice of its application.

\section{Conclusion}

Thus, the imperfection of the legal norms in force in modern Russia that enshrines the mechanism for applying the rules on parole, of course, implies their rethinking, updating and systematization on a new basis in accordance with the real and potential needs of law enforcement practice.

\section{Acknowledgements}

The work is performed according to the Russian Government Program of Competitive Growth of Kazan Federal University.

\section{References}

Aarten, P. G. M., Denkers, A., Borgers, M. J., \& Laan van der, P. H. (2014). Suspending re-offending? Comparing the effects of suspended prison sentences and short-term imprisonment on recidivism in the Netherlands. European Journal of Criminology, 11(6), 702-722.

Aral, S., Burris, S., \& Shearing, C. (2002). Health and the governance of security: A tale of two systems. Journal of Law, Medicine and Ethics, 30(4), 632-643.

Barygina, A. A. (2014). Procedural problems of applying the institution of parole from serving a sentence. Russian Justice, 2, 23-26.

Crewe, B., Warr, J., Bennett, P., \& Smith, A. (2014). The emotional geography of prison life. Theoretical Criminology, 18(1), 56-74.

Drozdov, A. I., \& Orlov, A. V. (2016). Problems of legislative regulation and practice of parole. Man: Crime and Punishment, 1(92), 89-95.

Efremova, I. A., \& Razgildiev, B. T. (2016). Legal nature of exemption from punishment. Vienna: East West» Association for Advanced Studies and Higher Education $\mathrm{GmbH}$.

Freiberg, A. (2011). Post-adversarial and post-inquisitorial justice: Transcending traditional penological paradigms. European Journal of Criminology, 8(1), 82-101.

Kachalova, O. V. (2015). Round table: Actual issues of judicial practice of exemption from punishment. Criminal law, 3. 119-121.

Moon, A. (2013). Liability of the police for the medical protection of persons in custody. Medico-Legal Journal, 81(2), 64-73.

Ratushny, E. E. (2016). The main directions of improving the legislation on parole from serving sentences. Modern Problems of the Social Sciences and Humanities, 6(8), 196-203.

Resolution of the Plenum of the Supreme Court of the Russian Federation of April 21, (2009). No. 8 (as amended on November 17,2015$)$ "On judicial practice of conditionally early release from serving a sentence, replacing the unserved part of a sentence with a milder type of punishment". Bulletin of the Supreme Court of the Russian Federation, No. 7.

Review of judicial practice of parole from serving a sentence (approved by The Presidium of the Supreme Court of the Russian Federation on 04.29.2014). URL: http://www.consultant.ru/document/cons_doc_LAW_162448/ (accessed: 05/30/2019).

Rhine, E. E., Petersilia, J., \& Reitz, K. R. (2015). Improving parole release in America. Fed. Sent'g Rep., 28, 96.

Rybakov, A. A. (2015). On the issue of improving control over persons released on parole. Library of Criminal Law and Criminology, 2(10), 133-136.

Simon, J. (2010). Do these prisons make me look fat? Moderating the USA's consumption of punishment. Theoretical Criminology, 14(3), 257-272.

Statistical data of the judicial department under the Supreme Court of the Russian Federation (form 1). URL: http://www.cdep.ru/index.php?id=79\&item=4891 (accessed: 05/30/2019). 